\title{
Integrative Therapy Focused on Trauma for People with Intellectual Disability (TIT-ID): A Therapeutic Answer to Abuse and Intellectual Disability Experience in the Individual and the Family
}

\author{
Mercedes Hernández Núñez-Polo*, Alberto Alemany Carrasco, Israel Berenguer Muñoz, \\ María Recio Zapata and Almudena Martorell Cafranga
}

Fundación Carmen Pardo-Valcarce, Victims with Intellectual Disability Support Unit (UAVDI), Monasterio de las Huelgas 15, 28049 - Madrid, Spain. Translated by María Ángeles Gil

\begin{abstract}
Persons with Intellectual Disabilities (ID) have ten times more risk of suffering abuse than persons without ID. When somebody is born with ID, his/her story is printed by trauma of ID (primary trauma). If we add the trauma from disability to the trauma from abuse (secondary trauma), we find very vulnerable population with a high probability of being re-victimised. Victim Support Unit for Persons with Intellectual Disability (UAVDI) proposes an Integrative Therapy focused on Trauma for people with ID (TIT-ID). This therapy is focused on trauma, including the victim and their families and professionals, through different approaches. It intervenes from individual pathoplasty, taking into account side effects caused by abuse. It also works from a systemic perspective of the primary trauma due to ID and primary grief in the individual and his family. It includes a person-centre intervention with attachment theory and organised through phases from theory of structural dissociation. It is very important to do a rigorous analysis of variables involved in the impact of grief (primary trauma) and later in the impact of abuse experience (secondary trauma). The goals of therapy will be planned according to the individual diagnosis. The cross-cutting objectives are the establishment of consistent links to enable the person to restore their feelings of security and sense of self-worth, and also the development of a resilient personality.
\end{abstract}

Keywords: Intellectual disabilities, abuse, trauma, PTSD, attachment, systemic approach, Integrative Therapy.

\section{PREVALENCE}

There are different studies on the high probability that persons with intellectual disabilities (ID) may suffer from abuse [1]. It is known that $60 \%-80 \%$ of people with intellectual disability have suffered an episode of abuse in their lifetime [2]. Some studies bring shocking data: the rate of sexual abuse victimisation is up to ten times higher, and the rate of theft is twelve times higher than in people without intellectual disabilities. There is also a high probability of repeat victimisation due to the fact that persons with intellectual disabilities are considered an easy prey since there are very little probabilities of detecting the abuse or of punishing the aggressor [3]. On the other hand, children with disabilities have more than twice as likely to be sexually abused, in comparison with children without disabilities [4, 5]. In addition, in the cases of abuse against persons with intellectual disabilities, the aggressor is normally known by the victim $[3,6]$. It is also important to be conscious that no-revelation is the rule: just $3 \%$ of abuse against persons with intellectual disabilities are revealed [7]. From this data it can be asserted that persons with ID are one of the most

*Address correspondence to this author at the Fundación Carmen PardoValcarce, Victims with Intellectual Disability Support Unit (UAVDI), Monasterio de las Huelgas 15, 28049 - Madrid, Spain; Tel: 0034917355790 ext.712306; Fax: 00349122437 19; E-mail: mercedes.hernandez@fcpv.es vulnerable groups to the different kinds of abuse and maltreatment.

In Spain, there are very little resources to support victims with intellectual disability. In 2010, the Carmen Pardo-Valcarce Foundation created the Victims with Intellectual Disability Support Unit (UAVDI, after its Spanish initials). From that date until November 2015, four hundred persons with ID that have suffered from abuse, have been attended in the UAVDI.

The strands of work in the UAVDI are:

- $\quad$ Prevention through workshops for persons with intellectual disabilities (ID) and their families on abuse detection

- $\quad$ Training for professionals that work with persons with ID

- $\quad$ Research to adapt the tools that are used in the judicial and therapeutic proceedings

- The role of the "facilitator": a psychologist expert in ID and testimony analysis that support the victims during the judicial proceeding to make all the necessary adaptations and avoid the secondary victimisation

- Make it possible to develop an integrative therapy to deal with trauma 


\section{INTELLECTUAL DISABILITY AND PRIMARY TRAUMA}

From the moment a person with intellectual disability is born, his/her story is going to be impressed in body, mind and spirit by the disability. This is the first trauma for that person, it is a first impact that alters the person and the family's balance, as well as the social context this person belongs to. This impact is called primary trauma $[8,9]$ and it will determine to a greater or lesser extent, the adaptation to the environment's demands. The elaboration of the mourning because of the disability starts at this moment. This trauma -the same as most of them- will be dynamic and changing and it will be activated regularly in different moments of the life cycle of the person with intellectual disability. This fact is very important and must be taken into account provided the complexity involved in the evaluation of psychological damage resulting from the abuse against persons with disability that, precisely because of the intellectual disability, have already an injury or previous traumas.

The news of pregnancy provokes in the whole family a wave of feelings: they fantasise about the child that is coming and how they will be as a family. A lot of wishes and expectations arise. Every birth of a child entails a frustration when facing wishes with reality. This frustration is increased with the news of a disability in the child: the distance between the wish and the reality is still greater. This fact produces feelings of bewilderment, sadness or fear that puts the family in a state of grief. So, talking about disability is the same as talking about grief: the parents' grief, the child's grief, the grief for the family's ideal or for the ideal way of family life. Thus, even though every family is unique and faces the experiences and problems in a different way, all the families that receive a diagnostic of intellectual disability of a child will have to face the grief of the child (or brother/sister, nephew/niece, grandchild, etc.) that they never had [10].

The study of this grief is really important, since its impact and the consequences of this grief for the family coincide in time with the need of the child to be cared and protected by the reference adults. This circumstance can endanger the well-being of every member of the family and the link with the child and, therefore, the basic care that the baby needs for the development of his psychic structure [9]. In this way, the establishment of the safe link attachment in the families with a child with intellectual disabilities becomes more and more difficult to achieve, nor just because of the parents' grief but also because of the intellectual disability itself: it implies special circumstances such as: the intervention in the family of external professionals to help the family with the care of the child from the moment of the detection of the disability; the many hospitalisations in the early childhood; or the fact that the baby may not be stimulating for the parents because of its limitations. The consequences of this emotional impact that results from the disability and the mourning process of the main carers of the baby with intellectual disability affect the development of three main aspects: the identity, the link and the affectivity and sexuality.

In relation to the identity development, if the family does not elaborate the grief for the desired child, other alterations will appear in the parents' identification mechanism. In these cases, the person with intellectual disability will just feel identified with the limitations of the disability but not with his/her personal abilities and strengths. Thus, his/her integrity, stability and wellbeing of the representation of himself will be damaged. The mark of this damage will be showed by the selfesteem deficit: the person with intellectual disability will create his/her identity outside of the reality with a fantasised self-esteem marked by the label of the disability. This label will cover the whole identity of the person, who will be reduced to his/her limitations, impossibilities and deficiencies.

For the development of the safe link attachment, it is not helpful if parents have a constant "concern looking" at the child [9]. One of the parents' most frequent fears is their child's suffering. This fear inevitably leads to the over-protection and control, which has negative consequences in the development of the subject's link [11]. The world's exploration, the differentiation between myself and the other (identity, wishes, etc.), the assumption of responsibilities, the emotional regulation, the privacy feeling and the perception of the world as a safe place are going to be seriously in danger. Over-protection and over-control make the individual growing-up stop, keeping the person in an eternal childhood.

The link between parents and child with intellectual disability is going to condition the development of affectivity and sexuality. Both of them, such as identity and attachment, have their origin at the moment of the birth and also in the meeting and the relationship with the other. The perception of the own body is determined in every person by the link (parents' wishes, type of contact) that parents establish with their 
baby. This corporal image determines the possibilities of an emotional and sexual life in everyone (the image of the body as a source of pleasure). In the case of babies with disabilities, many of the contacts between the carers and the children are more related to stimulation and therapeutic objectives than to the game and the pleasure, both of them, fundamental issues in the emotional development of a child. The parents can feel this child as a stranger. This can generate a rejection towards all physical contact with the person with intellectual disability. The development of sexual fundamental aspects such as privacy and intimacy can be deficient. The invasion of the intra-psychic space of the person with disability by his/her environment (overprotection and dependency) is a risk for the development of the own, private and intimate space. Thus, sexuality denial is common in persons with intellectual disabilities because of the mistaken belief that they are asexual or because the alarming idea that they have an uncontrolled sexuality that has to be contained. This denial is also a mechanism to avoid the separation between family and child with intellectual disability.

\section{ABUSE AND SECONDARY TRAUMA}

There is an abundant literature on the conceptualisation of abuse. Some authors talk about abuse as the imposition of a person over another from the basis of a relationship of power in order to please the person that exercises greater power through physical strength, threatening, cheating, intimidation, using the confidence or affection or other forms of pressure [12-14]. These conceptualisations can be transferred to the persons with intellectual disabilities since these persons are more susceptible of being tricked or coerced or threaten, because of their maturity level in comparison to the aggressors [15] and the vulnerability factors that will be analysed further on.

In many cases, the consequences of the abuse are going to be identified through behavioural changes or the symptomatology. Making a brief revision in the literature, the symptomatology that persons with intellectual disabilities (ID) present after a traumatic event is very diverse and nonspecific. Some authors have described the consequences of an abuse in persons with intellectual disabilities [16-24]. This symptomatology is nonspecific, which is partially due to the lack of evaluation tools adapted to the persons with intellectual disability [25]. Another characteristic that makes it difficult to identify the symptoms is the pathoplasty. The pathoplasty refers to the fact that mental health problems appear in a different way in persons with intellectual disabilities. The clinical manifestations in persons with intellectual disabilities differ from the ones in the general population, so it will be necessary for the professionals involved (direct support professionals, forensic experts and psychotherapists) to know the pathoplasty of the trauma in persons with ID. Thus, making a diagnosis becomes more difficult because of the pathoplasty but also because of the communication limitations and in the cognitive function, because of the primary trauma and of the so called diagnostic overshadowing [26, 25]. The diagnostic overshadowing refers to the professional's tendency to consider the ID the cause of the psychiatric symptoms: the ID overshadows the presence of a mental disorders. In this way, the context that surrounds a person with ID normally attribute the psychiatric symptoms to the ID instead of to the mental health problems of these persons or to the consequences of the abuse. This effect limits the initiation of the diagnostic and intervention systems for mental disorders in these persons.

The ID also produces a distortion in the professional's clinical judgement that implies the minimisation of the mental health problem's relevance and its meaning and importance for the patient's wellbeing. Therefore, the differences between the symptomatology of a person with a mental disease and the rest of the population are greater. For this reason, it is necessary to develop adapted criteria for these persons. That process should end up with the creation of specific diagnostic manuals adapted such as the DC-LD [27] or the DM-ID [28].

Due to the lack of specificity of the signs and symptoms we can't talk about an "abuse syndrome" in persons with ID that makes it possible to detect those situations through the symptomatology. Despite the limitations, it would be interesting to make an effort to discern between the manifestations of psychic damage that are a consequence of the "primary trauma", and the ones that are derived from the situation of criminal victimisation, that is, the "secondary trauma".

\section{ASSESSMENT THE IMPACT OF SECONDARY TRAUMA}

Any abusive conduct is based on the use of power and control over another person. It is done through instruments of violence such as humiliation, guilt and lack of empathy, and attack against the helplessness 


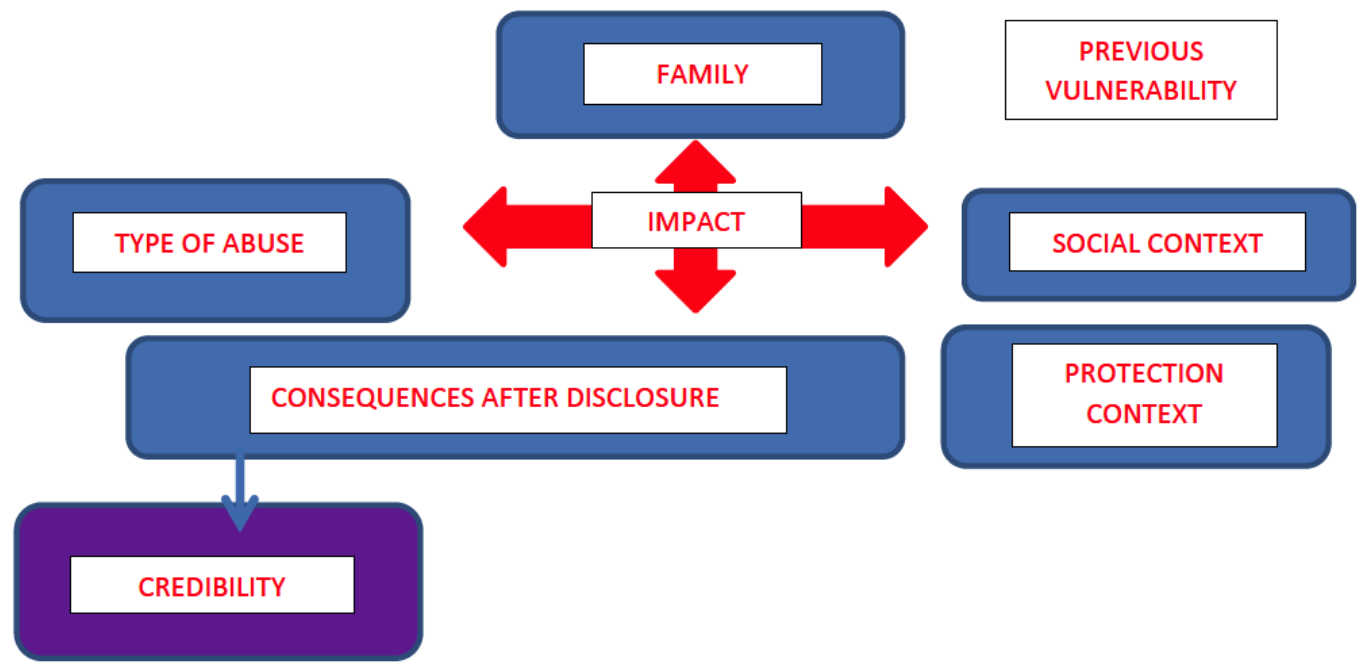

Figure 1: Assessment the context of impact from abuse.

and vulnerability of the individual [29]. Another key of the trauma caused by an abusive situation, is based on the relationship of cruelty that tears human trust [30]. If we add the damage generated from abuse and the trauma of disability (this is the primary trauma: from his/her childhood, the individual has been damaged and looked as no capable), we have a very vulnerable population with a high probability to be re-victimised because of a number of reasons: their communication skills limitations, the lack of credibility, their dependence, the lack of adaptation in the police and judicial systems, the suffering multiplied by the reenactment of a primary and secondary trauma, and the breakdown of the family, among other vulnerabilities.

In the context of assessing the impact of abuse (secondary trauma) (Figure 1) with a victim with ID, protective and vulnerability factors should be contemplated. The damage, injuries or the consequences that a traumatic experience have in the victim, will depend on the characteristics of the traumatic situation, on the individual personality variables of the victim, on the family variables and on the context variables. Regarding the context of protection, judicial and police procedures around the victim with ID, are going to be important to provide the necessary support through professional experts to avoid a process of re-victimisation [31].

In Figure 2, we present the factors that have an influence on the impact of abuse. The vulnerability factors have a greater influence in the case of persons with ID. The emotional impact from abuse will be greater and so, it will be necessary to make a good assessment of the protective factors that can attenuate this impact.

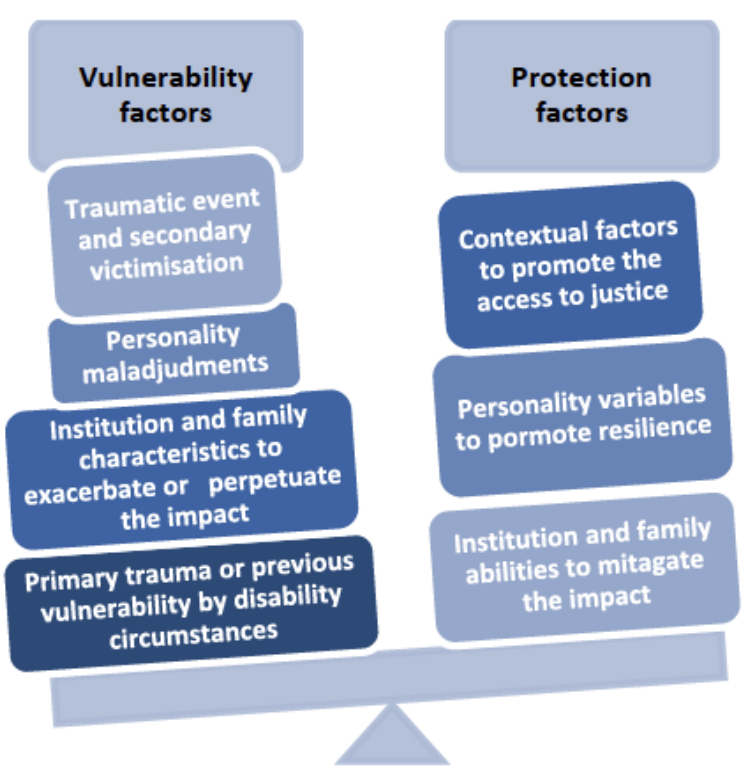

Figure 2: Factors that influence the impact of abuse.

Núñez [9] makes a review of the factors to consider in the psychological evaluation of traumatic experiences. These are:

- Quantitative parameters: frequency, intensity and duration of the abuse

- Qualitative parameters: level of harassment or humiliation

- The link of affection with the perpetrator

- The multiple negative consequences of abuse

There are some other factors to take into account. Vallejo Samudio, Terranova Zapata [32] describe the "second traumatic injury" in the context of revelation 
due to the perception of the lack of credibility of the testimony. There is also an effect of "re-victimisation" caused by the inability of the system to adapt procedures to the victims with intellectual disabilities and by the lack of tools to evaluate the credibility for these persons. For example, the victims have to make their statements more times than necessary without being aware of their cognitive difficulties (communication, memory, spatial-temporal orientation, quantification, etc.).

Throughout this process, it is important to include the concept of Secondary Post-Traumatic Stress Disorder (Secondary PTSD). Although it is not included in the diagnostic criteria DSM-V and ICD-10, it has been described in the literature [33]. It suggests that people can be traumatised directly and indirectly. Secondary PTSD refers to any type of transfer of the anxiety from someone who experienced trauma, to their environment, and includes similar symptoms to Post Traumatic Stress Disorder [34]. We cannot ignore the fusion that occurs between the life cycle of the person with intellectual disability and his/her context because of their dependence and overprotection. The families can manifest Secondary PTSD symptoms. Therefore, it is important to include in the therapeutic process the nearest social context of the victim, such as the family.

\section{THE INTEGRATIVE THERAPY FOCUSED ON TRAUMAS FOR PERSONS WITH INTELLECTUAL DISABILITIES (TIT-ID)}

Persons with ID have been marginalised in psychotherapy. There is a myth that disability protects them from the negative feelings that cause traumatic experiences. However, they feel like everyone else, but the therapy will have to be adapted to their peculiarities. In this regard, studies show that people with ID are more likely to develop mental illnesses than people without ID [35-37], with lower levels of resilience to face traumatic events or stressful life events [38].

It is a fact that persons with ID benefit from psychotherapy and even from the most dynamic approaches, as any persons without disabilities [39]. The professional will have to make the necessary adaptations -as in any other context- in order to diagnose and intervene with them.

In general, when we work in therapy with people who have suffered some kind of trauma, the first principle is the recovery of the power of the victim [40]. The "power of capacity" has been snatched in most of persons with intellectual disabilities since the disability is diagnosed. Their self-concept has been defined from the disintegration and no capacity. The persons with disabilities will create a vision of the world from their Internal Working Models (IWM) [41]. When they suffer an abuse, the damage of these people is a verification of their own IWM: they see the world as threatening and negligent and that will abandon them. In those IWM they see themselves as deserving of damage without protection. Abuse speaks about their lack of tools and resources, their lack of ability to "cope" and their dependency: they confirm their disability. For the therapist it must be fundamental that the person with ID regain the power, his/her own control, dignity and integrity, safety and confidence, not only in human beings but also in his/her own person. In summary, to reach "the power of THEIR OWN capacity."

The Integrative Therapy focused on Traumas for people with ID (TIT-ID) seeks to integrate different frames of action. The therapist intervenes from individual pathoplasty, taking into account the side effects caused by abuse. It also works from a systemic perspective of the primary trauma -due to ID- and primary grief in the individual and his family. It includes a person-centred intervention with attachment theory and organised through phases from theory of structural dissociation.

\section{Intervention from the Knowledge of the Pathoplasty with Persons with ID}

In TIT-ID, the person carrying out the psychotherapy must know the pathoplasty in people with ID, for two reasons: first, the symptoms show the impact that traumatic experience has left on the person, and second it is one of the first ways the therapist has to communicate with his/her patient and to establish a therapeutic alliance. Finally, knowing the pathoplasty will create contexts that may contain, regulate and, therefore, heal.

Any diagnostic map and psychotherapeutic intervention strategy that have traditionally been used with traumatised people, should be adapted to people with ID.

Finkelhor and Browne [42] reported several reasons of the traumatic impact of sexual abuse: traumatic sexualisation, loss of confidence, helplessness and stigmatisation that is greater if the abuse has happened during the childhood and has been prolonged in time. This leads to a distortion of self-concept and worldview. 
We may well use the same reasons to explain the trauma in persons with ID:

- The persons with ID will live, most likely, a traumatic sexuality because, for them, it has been forbidden, secret and therefore, disturbed. After the abuse, sexuality is more disturbed.

- $\quad$ Barriers they face throughout their lives because of an uncomprehensive society, devour their potential confidence in the world. After the abuse, suspicion is confirmed. This person is going to lose the trust in the human being and in himself/herself.

- $\quad$ Finally, there are two concepts associated with the experience of disability: helplessness and stigmatisation. Those concepts take special importance after the abuse: the helplessness, because they have found that their skills to face life were not valid; and the stigmatisation, because the isolation increases after the disclosure.

This explains the importance of working with the primary trauma of disability and not only with the traumatic experience -secondary trauma- [24] in the psychotherapeutic context.

In addition, there will be multiple traumas that will define the identity of persons with ID. Since the primary trauma, frequent re-enactments are going to happen throughout their entire life cycle. We can often find painful situations such as social discrimination, academic failure, perception of not being able, etc. A re-edition of traumatic experiences occurs. Therefore, when the original trauma is known, the therapist can find a striking similarity between the primary trauma and re-enactments [40], so we can understand and explain the mechanisms that are acting on the individual. To be more explicit and from the Quality of Life Dimensions Model of Schalock and Verdugo [43, 44], we may establish equivalences that explain the reactivation of the trauma of the person with ID who has suffered abuse Table 1. This offers a global vision for the organisation of the therapy in the TIT-ID.

\section{Therapeutic Approach to Primary Trauma and Family Mourning}

In order to provide a suitable therapeutic approach, we must have a global perspective of the person and the family, and the life cycle. The family is a system in continuous movement that is modified depending on different circumstances:

- Evolutionary changes: Changes due to the pass from an evolutionary stage to another (constitution of the couple, first birth, schooling of children, etc.) [45]. The set of these evolutionary stages in the family is called family life cycle [46].

- Accidental changes: these are non-expected events. These appear suddenly (accidents,

Table 1: Equivalence of the Primary and Secondary Trauma of People with ID Victims of Abuse

\begin{tabular}{|l|l|l|}
\hline QUALITY OF LIFE DIMENSIONS* & PRIMARY TRAUMA AND ID & SECONDARY TRAUMA AND ABUSE \\
\hline \hline EMOTIONAL WELL-BEING & Self-concept defined from the NO Capacity & NO Capacity self-concept is reaffirmed \\
\hline MATERIAL WELL-BEING & $\begin{array}{l}\text { Limits on education, leisure and employment } \\
\text { options. Dependence. }\end{array}$ & $\begin{array}{l}\text { The options become more limited. } \\
\text { Increased dependence. }\end{array}$ \\
\hline $\begin{array}{l}\text { PERSONAL DEVELOPMENT AND } \\
\text { PHYSICAL WELL-BEING }\end{array}$ & $\begin{array}{l}\text { They grow with established limitations, both } \\
\text { psychological and physical }\end{array}$ & $\begin{array}{l}\text { Decrease in the overcome limitations. Loss } \\
\text { of skills and capacities. }\end{array}$ \\
\hline $\begin{array}{l}\text { INTERPERSONAL RELATIONS AND } \\
\text { SOCIAL INCLUSION }\end{array}$ & $\begin{array}{l}\text { Isolation, social exclusion, discrimination, } \\
\text { stigmatisation, social development issues and } \\
\text { integration into society issues. }\end{array}$ & $\begin{array}{l}\text { The abuse causes a distrust in the human } \\
\text { being and isolation of the person from the } \\
\text { world. } \\
\text { The options become more limited, due to } \\
\text { overprotection or loss of their relatives } \\
\text { (domestic abuse) }\end{array}$ \\
\hline SELF-DETERMINATION AND RIGHTS & $\begin{array}{l}\text { Limitation on their right. Right to decide about } \\
\text { their life, right to their sexuality, to be heard, } \\
\text { to be loved, right to be looked at from } \\
\text { capacity }\end{array}$ & $\begin{array}{l}\text { Reaffirmation of the limitation of their rights. } \\
\text { Lack of credibility after the revelation of the } \\
\text { abuse. } \\
\text { Limitation in the options if they want to fill a } \\
\text { complaint. Lack of adjustment in the judicial } \\
\text { process, so they don't have the same rights. }\end{array}$ \\
\hline
\end{tabular}

*Schalock, R.L. \& Verdugo, M.A. (2007). El concepto de calidad de vida en los servicios y apoyos para personas con discapacidad intelectual. Siglo Cero, 38(4), 2136 
unemployment, abuse, birth of a child with ID, etc.). Many of them become a family crisis.

These changes consequently modify the positions of the family members in the group, the rules in the family, the tasks it has to face, and as a result, the experiences of each member change. The families with a child with ID must re-structure and modify the marital system to a parental system (they go from being just man-woman, to be man-woman-baby). They will also have to face and accidental crisis, since the ID child's birth [47]. Disability will determine the way of dealing with the different developmental tasks, and will affect the family's ability to establish a functional structure with a hierarchy and clear limits.

The deal of secondary trauma (abuse), can hardly be done without considering the possible primary trauma that disability may have left in the family and in the individual. The TIT-ID offers a proposal to manage those factors of family mourning with a member with ID. Therefore, working with a family with a person with ID must always start from a research on the primary grief to continue with the deal of the secondary trauma.

\section{Person-Centred Intervention as an Agent of his Own Life}

It is common that the person with ID delegates the management of his own life to others, such as family or professionals. The IWM, influenced by the primary trauma, develop an identity based on the "no-capacity" of the person with ID to address the difficulties of life or to interact with the environment. In clinical practice, it is common to see people with ID who are not "able" to deploy capabilities that have acquired. That vision of themselves, with the disability label, makes them null.

Therefore, when a person with ID have to face the difficult consequences of an abuse, this person will find the same difficulties that have been found throughout his life: a feeling of failure that even cancel the best of their qualities.

TIT-ID proposes a person-centred intervention for people with ID, because it is about their lives on which we are working. Through psychotherapy, the rudder of the life of the person with ID must to move from the environment (family and professionals) to the individual. As discussed previously, people are relational beings and will work in harmony with the looking of others. If the look at from psychotherapy which is returned to the person is according to capacity, value and power, this person will become as someone capable, valid and empowered.

\section{Psychotherapy Focused on Attachment Theory}

People with ID traumatised by a violent act may show a variety of symptoms, and the impact may depend on many factors, but they have in common their feeling unsafe, the fear and lack of protection due to the characteristics of the traumatic experience. This is the reason why, the psychotherapy will not only focus on the traumatic experience itself, but in the creation of a protective environment. Unlike other cognitive therapies focused on trauma, in the intervention from the model we propose (TIT-ID), the main objective will be weaving links of safety and trust with those close and meaningful relatives of the person with ID.

The work of Bowlby [41, 48, 49] and Ainsworth [50], have contributed to that attachment theory has become the best founded theory about the children emotional development [51]. The attachment is aimed to meet the need for safety and protection. It refers to any behaviour that looks for the other's proximity, who is considered a source of relief and well-being [52]. Recall that the establishment of a safe attachment for a person with ID with their primary caregivers, is often threatened by the process of family mourning -primary trauma-.

In order for a child to develop properly, he/she needs to make a positive impact on the significant people of his/her life. The problem with children with ID is that this impact is often negative. Anger, communication problems, the challenges of diagnosis, learning disabilities, can create doubts in the parents about their skills, and thus, they will feel vulnerable and insecure in front of the child with ID. The worth as parents is constantly questioned. The longer the history of unsafe attachment the parents have, the greater negative effect it will have on the child. The history of parents with a child with ID, usually starts with an emotional trauma, with pain, shock, sorrow and sense of injustice, of being different. If these feelings are the ones that they experienced in their childhood, before being parents, they could be magnified in the parental experience with a child with ID [53].

Thus, including attachment theory in the TIT-ID can deal the primary trauma of disability and the secondary trauma of abuse. It also constitutes the basis for changing the IWM of self and of the world [54]. 
Only if the person feels worthy of care and confident that significant others will come to his/her help when problems of life arrive, he/she can be encouraged to explore and, consequently, develop his/her selfconcept and self-esteem. Only if a person feels loved, this person can feel valuable. Therefore, the therapy based on the attachment theory includes a crucial factor (security and protection: the safe attachment link) which can help to restore the damage in his/her identity. The identity refers to the integrity and balanced representation of the self, which in people with ID is usually damaged.

\section{The Theory of Structural Dissociation of the Personality: Phases of the Intervention}

The theory of structural dissociation is based on a phase-oriented model. The original idea comes from Pierre Janet, pioneer in this idea $[40,55]$. Although the phases have been described on a linear basis, actually they are flexible and recurrent, involving the need to return to the previous stages [55]. In ID, the trauma is re-enacted in every stage of life, and crises (in our case, the abuse). Therefore, we could speak of a structural cyclical process of the person. The TIT-ID has adapted these phases of the psychotherapy process to people with ID (Table 2).

Table 2: Psychotherapy Phased Framework

\begin{tabular}{|c|c|c|}
\hline Phases* & People without ID* & People with ID adaptation \\
\hline 1. Safety and stabilisation & $\begin{array}{l}\text { People affected by trauma tend to feel unsafe } \\
\text { in their bodies and in their relationships with } \\
\text { others. In order to move towards recovery, it } \\
\text { will be necessary to figure out what areas of life } \\
\text { need to be stabilised and how that will be } \\
\text { achieved. This phase also promotes } \\
\text { recognition of external and internal conditioned } \\
\text { stimuli that evoke the trauma and modulation of } \\
\text { responses to these impulses. }\end{array}$ & $\begin{array}{l}\text { - Knowing pathoplasty and assessing the impact } \\
\text { and the psychological damage; establishing a } \\
\text { therapeutic alliance (family/context and individual) in } \\
\text { order to stabilise. } \\
\text { - Assessing those stimuli that evoke and maintain } \\
\text { the trauma, re-actualisations from the primary } \\
\text { trauma, for which will be essential to have it defined } \\
\text { by the dimensions of Quality of Life. } \\
\text { - Establishing trust and safety, and developing a } \\
\text { safe attachment link. This phase is going to be } \\
\text { crucial for the progression of the therapy. }\end{array}$ \\
\hline 2. Remembrance and mourning & $\begin{array}{l}\text { Processing the trauma, putting words and } \\
\text { emotions. It should integrate trauma story } \\
\text { without a fight, flight or freeze response. } \\
\text { If the person is overwhelmed and flooded } \\
\text { emotionally when talking about their memories } \\
\text { of trauma, security and stability must be } \\
\text { restored before going further with the story. } \\
\text { The point is not "re-live" the trauma, but neither } \\
\text { is telling the story without emotion. It is } \\
\text { important to explore and to grieve for the } \\
\text { losses associated with the trauma and provide } \\
\text { space to express their emotions. }\end{array}$ & $\begin{array}{l}\text { - Giving space to feel victim and expressing it with } \\
\text { support. It is important to confirm and to be aware of } \\
\text { the different events that were creating the primary } \\
\text { trauma. } \\
\text { - Telling story from the primary trauma and to evolve } \\
\text { into the secondary trauma: the primary trauma is } \\
\text { determined not only by the past interactions but also } \\
\text { by the type of relationship established with the } \\
\text { nearest context. This work has to be done taking } \\
\text { into account the context in order to change that link } \\
\text { (overprotection / abandonment). This work has to } \\
\text { merge between the person with ID and his } \\
\text { context/family. } \\
\text { - The story of the individual and the mourning } \\
\text { process of their own disability: putting words to } \\
\text { emotions. In ID, sometimes techniques beyond the } \\
\text { word are used. The narrative can be done from } \\
\text { creative techniques, symbolic techniques, play } \\
\text { therapy techniques, etc. } \\
\text { - Working through the primary grief in the family. } \\
\text { - The therapist establishes a swinging in the story } \\
\text { telling of trauma (using other topics than the } \\
\text { traumatic event) not to overwhelm the individual and } \\
\text { their context/family. } \\
\text { - Only once the primary trauma has been made and } \\
\text { the internal operating models (about the person, } \\
\text { and the person in the world) have a solid structure, } \\
\text { the work on the secondary trauma can be possible. }\end{array}$ \\
\hline 3. Reconnection and Integration & $\begin{array}{l}\text { Creating a new sense of self, redefining the } \\
\text { self. The trauma is no longer a definition or the } \\
\text { focus of his/her }\end{array}$ & $\begin{array}{l}\text { - Definition of the new self-concept where parts of } \\
\text { the person and context/family are integrated. }\end{array}$ \\
\hline
\end{tabular}

"Adapted from Herman, J. (1992). Trauma and Recovery, Glenview, IL: Basic Books (Harper Collins). 


\section{OUR EXPERIENCE: VICTIMS WITH INTELLECTUAL DISABILITY SUPPORT UNIT (UAVDI)}

Since 2010 UAVDI has attended 374 people with intellectual disability victims from abuse. 160 were under therapeutic process (the Integrative Therapy focused on trauma for persons with Intellectual Disability: TIT-ID). At the moment, 54 people are still under therapy and 106 people were discharged. In the area of therapy, the sample (Table 3 ) consists of $76 \%$ of women and $24 \%$ of men. About age, $61 \%$ are adults, $30 \%$ are adolescents between 13 and 18 years old and $9 \%$ are children under 13 years old.

It is important to highlight the fact that some of these patients have suffered more than one type of abuse. According to the Figure 3, the most common type of abuse is domestic sexual abuse (24\%) followed by sexual harassment abuse by others $(20 \%)$ and peer sexual abuse $(16 \%)$. The abuse is higher in the family, by some relative or person emotionally close, so the traumatic experience is bigger, due to the link of affection with the perpetrator.

\section{Methodology}

1. First interview: the welcome phase. This is the moment where we start to develop a safe and trust relationship with the patient and evaluate their emotional stage. The evaluation consists of a brief semi-structured interview.

2. Second interview: including the patient, this is the moment to establish the "Individual Care Plan" (PIA - Plan Individual de Atención - after its Spanish initials). The common goals for all the patients are:

- Positive adjustment in their environment: family, occupational centre, home care, school, work place.

- Reduction of the symptoms: flash backs, specific phobias (places, topics, people), sleep disorders, anxiety symptoms and depression symptoms.

Furthermore, the patient and the psychologist sign a therapeutic commitment contract for one year.

3. First therapeutic session: the therapeutic process as such starts at this moment. The different phases are presented in Table 2.

\section{Results}

The period of the therapeutic process is one year with the possibility to extend to six more months

Table 3: Demographic Data

\begin{tabular}{|c|c|c|c|}
\hline Gender & \multicolumn{2}{|c|}{ Female } & Male \\
\hline & \multicolumn{2}{|c|}{$76 \%$} & $24 \%$ \\
\hline Age & Under $\mathbf{1 3}$ & Adolescents $\mathbf{1 3 - 1 8}$ & Adults \\
\hline & $9 \%$ & $30 \%$ & $61 \%$ \\
\hline Number of Cases & \multicolumn{2}{|c|}{ On therapy } & Finish the therapy \\
\hline & \multicolumn{2}{|c|}{54} & 106 \\
\hline
\end{tabular}

\section{Type of abuse}

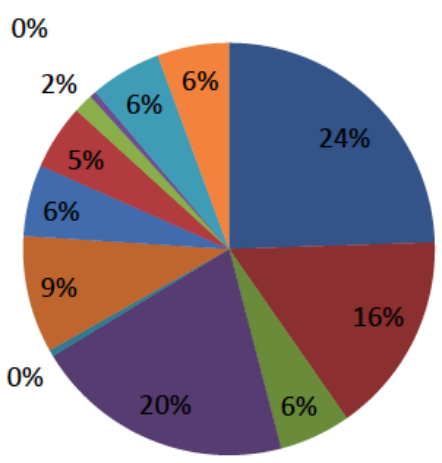

Domestic sexual

abuse

- Peer sexual abuse

Sexual harassment by

workers

- Sexual harassment by

others

Human trafficking

Gender violence

Figure 3: Type of abuse. 


\section{Discharged cases}

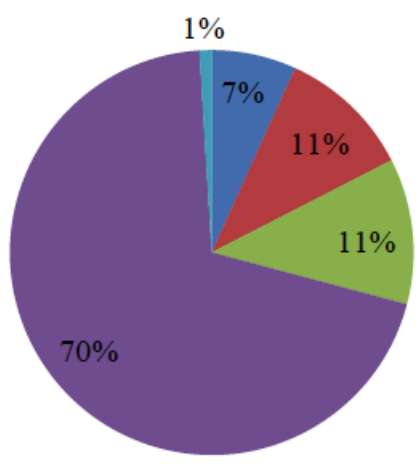

Figure 4: Discharged cases.

depending on three criteria: the severity of traumatic experience, the vulnerability factors that influence the impact of abuse (Figure 2) and the adjustment of primary trauma. The discharge is done when the PIA goals are achieved, that is to say, when the symptoms are reduced and the patient learns to control and identify them; and also when the person with ID is able to start an adjustment to the environment (personal and social).

In 106 cases, the patients were discharged (Figure 4) for different reasons: $70 \%$ of the cases achieved the PIA goals; $1 \%$ of the patients never came to the therapy; after psychological assessment, it was found out that $7 \%$ did not really need a therapy; $11 \%$ stopped voluntarily the therapy due to different circumstances, for example change of address or city, or change of psychologist closer to their places. Finally, $11 \%$ of the patients were discharged without achieving all PIA goals, because the UAVDI team decided to stop the therapy due to the complication of the case (extra mental health disorders, autism spectrum disorder, etc.). In other cases, the patients systematically cancelled the session and it was not possible to established safe attachment link.

\section{CONCLUSION}

When a baby with ID comes into his family, an impact occurs due to the distance between the ideal baby they were waiting for and the reality. This distance between ideal and reality leads to a process of mourning in the family -primary trauma-. This primary trauma will influence the care and parental roles in the family, compromising some crucial aspects in the subsequent identity configuration of the person with ID. The identity of the person with ID will be strongly defined by the disability itself; by the attachment links

\author{
No need of therapy \\ - Voluntary discharge \\ Other reasons (assessment of \\ the therapist) \\ noals achieved \\ Never came to therapy
}

created by the pain of parents; and by a distorted affection and sexuality. These consequences will be reflected in the IWMs of the person (world as hostile, not welcoming and insecure; and the person himself as incapable and undeserving of positive experiences).

When the abuse -secondary trauma- occurs in the life of the person with ID, all past experiences of these Internal Working Models are re-enacted. The experience of abuse, is a further confirmation of everything that a person and his family have had to live in different phases of their life cycle. For this reason, for the assessment of the impact of abuse -secondary trauma-, we must take into account the primary trauma.

The TIT-ID proposes a form of psychotherapy with the person with ID, victim of any traumatic experience, and his/her family. The TIT-ID, from a dynamic/nonstatic vision of the trauma-related structural dissociation theory, addresses the trauma in an integral manner. To do so, the specialist should be familiar with ID peculiarities and its form of mental health expression: the pathoplasty. Secondary trauma can only be addressed after working through primary trauma with the person and his/her family context. The process of change is heavily focused on the persons with ID as agents of their own lives, and the development of safe attachment links. From those links, the persons with ID will be able to create new Internal Working Models about himself/herself and the world around him/her. In this way, the persons with ID can establish a relationship with the world from THEIR capacity, THEIR autonomy and with THEIR strength.

\section{FURTHER RESEARCH}

The data shown in this descriptive analysis is based on non-standardised criteria, using a heterogeneous sample. In spite of these limitations, the results talk 
about a promising intervention focused on trauma for people with ID victims from abuse, given that $70 \%$ of the cases achieved the goals. In order to evaluate the efficacy of the TIT-ID from an experimental perspective, a two-phase prospective control study has been established with pre and post intervention assessment. This study has not been completed yet but hopefully, they will be published next year.

\section{REFERENCES}

[1] Sobsey D, Gray S, Wells D, Pyper D, Reimer-Heck B. Disability, sexuality, and abuse: An annotated bibliography. Baltimore: Paul H. Brookes 1991.

[2] Levy H, Packman W. Sexual abuse prevention for individuals with mental retardation: considerations for genetic counselors. Journal of Genetic Counseling 2004; 13(3): 189205.

http://dx.doi.org/10.1023/B:JOGC.0000028158.79395.1e

[3] Reiter S, Bryen DN, Shachar I. Adolescents with intellectual disabilities as victims of abuse. Journal of Intellectual Disabilities 2007; 11(4): 371-387. http://dx.doi.org/10.1177/1744629507084602

[4] Marini Z, Fairbairn L, Zuber R. Peer harassment in individuals with developmental disabilities: Toward the development of a multidimensional bullying identification model. Developmental Disabilities Bulletin 2001; 29: 170195.

[5] Vig S, Kaminer R. Maltreatment and developmental disabilities in children. Journal of Developmental and Physical Disabilities 2002; 14(4): 371-386.

http://dx.doi.org/10.1023/A:1020334903216

[6] Curry MA, Renker P, Hughes RB, Robinson-Whelen S, Oschwald M, Swank PR, Powers LE. Development of Measures of Abuse Among Women with Disabilities and the Characteristics of Their Perpetrators. Violence Against Women 2009; 15(9): 1001-1025. http://dx.doi.org/10.1177/1077801209340306

[7] Valenti-Hein D, Schwartz L. Sexual abuse interview for those with developmental disabilities. Santa Barbara, CA: James Stanfield Company 1995.

[8] Muntaner JJ. La sociedad ante el deficiente mental: Normalización, integración educativa, inserción social y laboral, Madrid: Narcea 1998.

[9] Núñez B. La familia con un hijo con discapacidad: sus conflictos vinculares. Archivos Argentinos de Pediatría 2003; 101(2): 133-142.

[10] Paniagua G. Desarrollo psicológico y educación. Madrid: España 2001.

[11] Recio M, Pozo P, Rodríguez M. Las dificultades de ser adolescente hoy. Un panóptico en la familia. En R, Pereira (ed.), Adolescentes en el siglo XXI: entre impotencia, resiliencia y poder (150-161). Madrid: Morata 2011.

[12] Barudy J. El dolor invisible de la infancia. Una lectura ecosistémica del maltrato infantil. Barcelona: Paidós 1998.

[13] Finkelhor D, Strapko N. Sexual abuse prevention education: A review of evaluation studies. In D. Willis, E. Holder, \& M. Rosenberg (Eds.). Child abuse prevention. New York: Wiley 1992.

[14] Verdugo MA, Alcedo MA, Bermejo B, Aguado AL. El abuso sexual en personas con discapacidad intelectual. Psicothema 2002; (14): 124-129.

[15] Santín LV. Abuso sexual y discapacidad intelectual. Estudio de 5 Casos de jóvenes con discapacidad intelectual con presunción de abuso sexual 2012. Come from: http://dspace.ups.edu.ec/handle/123456789/5590
[16] Ghaziuddin M, Alessi N, Greden JF. Life events and depression in children with pervasive developmental disorders. Journal of Autism and Developmental Disorders 1995; 25(5): 495-502.

http://dx.doi.org/10.1007/BF02178296

[17] Ryan R. Post-traumatic stress disorder in persons with developmental disabilities. Community Mental Health Journal 1994; 30(1): 45-54. http://dx.doi.org/10.1007/BF02188874

[18] Howlin P, Clements J. Is it possible to assess the impact of abuse on children with pervasive developmental disorders? Journal of Autism and Developmental Disabilities 1995; 25(4): 337-354.

http://dx.doi.org/10.1007/BF02179372

[19] Stavrakaki C, Mintsioulis G. Anxiety disorders in persons with mental retardation: diagnostic, clinical and treatment issues. Psychiatric Annals 1997; 27: 182-189. http://dx.doi.org/10.3928/0048-5713-19970301-10

[20] Hardan A, Sahl R. Suicidal behavior in children and adolescents with developmental disorders. Research in Developmental Disabilities 1999; 20(4): 287-296.

http://dx.doi.org/10.1016/S0891-4222(99)00010-4

[21] McCarthy J. Post-traumatic stress disorder in people with learning disability. Advances in Psychiatric Treatment 2001; 7: 163-169.

http://dx.doi.org/10.1192/apt.7.3.163

[22] Peckham NG. The vulnerability and sexual abuse of people with learning disabilities. British Journal of Learning Disabilities 2007; 35(2): 131-137. http://dx.doi.org/10.1111/j.1468-3156.2006.00428.x

[23] Lovell A. Learning disability against itself: the self-injury/selfharm conundrum. British Journal of Learning Disabilities 2007; 36(2): 109-121.

http://dx.doi.org/10.1111/j.1468-3156.2007.00477.x

[24] Sinason V. Psychotherapy with profoundly handicapped children. In S. Ramsden (ed.), Psychotherapy - Pure and Applied: Papers and Workshops Presented at the ACPP Study Day (38-42). London: Association for Child Psychology and Psychiatry 1992.

[25] Mevissen L, Jongh A. PTSD and its treatment in people with intellectual disabilities: A review of the literature. Clinical Psychology Review 2010; 30(3): 308-316. http://dx.doi.org/10.1016/j.cpr.2009.12.005

[26] Reiss S, Szyszko J. Diagnostic overshadowing and professional experience with mentally retarded persons. American Journal of Mental Deficiency 1983; 87(4): 396-402.

[27] Royal College of Psychiatrist. DC-LD: diagnostic criteria for psychiatric disorders for use with adults with learning disabilities/mental retardation, London: Gaskell Press 2001.

[28] Fletcher R, Loschen E, Stavrakaki C, First M. Diagnostic manual-intellectual disability (DM-ID). A clinical guide for diagnosis of mental disorders in persons with intellectual disability. Kingston, NY: NADD Press 2007.

[29] Mollica RF. Healing invisible wounds: paths to hope and recovery in a violent world. Nashville, TN: Vanderbilt University Press 2006.

[30] Shatan CF. Trastorno de estrés postraumático: entrevista con Chaim F. Shatan. Reunión de la Sociedad Española de Psicotraumatología y Estrés Traumático, S.E.P.E.T. Aperturas Psicoanalíticas. Revista de Psicoanálisis junio 2000, 9. Come from: http://www.aperturas.org/articulos.php? id=184\&a=Trastorno-de-estres-postraumatico-entrevista-conChaim-F-Shatan

[31] Recio M, Alemany A, Manzanero A.L. La figura del facilitador en la investigación policial y judicial con víctimas con discapacidad intelectual. Siglo Cero. Revista Española sobre Discapacidad Intelectual 2012; 43(3): 54-68. 
[32] Vallejo AR, Terranova LM. Estrés postraumático y psicoterapia de grupo en militares. Terapia psicológica 2009; 27(1): 103-112. http://dx.doi.org/10.4067/s0718-48082009000100010

[33] Klarić M, Kvesić A, Mandić V, Petrov B, Frančišković T. Secondary Traumatisation and Systemic Traumatic Stress. Medicina Academica Mostariensia 2013; 1(1): 29-36.

[34] Dekel R, Solomon Z. Marital relations among former prisoners of war: contribution of posttraumatic stress disorder, aggression, and sexual satisfaction. Journal of Family Psychology 2006; 20(4): 709-12. http://dx.doi.org/10.1037/0893-3200.20.4.709

[35] Cooper SA, Bailey NM. Psychiatric disorders amongst adults with learning disabilities: prevalence and relationship to ability level. Irish Journal of Psychological Medicine 2001; 18, 45-53.

[36] Emerson E, Kiernan C, Alborz A, Reeves D, Mason H, Swarbrick R, Hatton C. The prevalence of challenging behaviors: a total population study. Research in Developmental Disabilities 2001; 22(1): 77-93. http://dx.doi.org/10.1016/S0891-4222(00)00061-5

[37] Martorell A. Discapacidad intelectual y Salud Mental. Autonomía personal 2011; 5: 38-43.

[38] Martorell A, Tsakanikos E, Pereda A, Gutiérrez-Recacha P, Bouras N, Ayuso-Mateos JL. Mental health in adults with mild and moderate intellectual disabilities: the role of recent life events and traumatic experiences across the life span. Journal of Nervous and Mental Disease 2009; 197(3): 182186.

http://dx.doi.org/10.1097/NMD.0b013e3181923c8c

[39] Cottis T. Intellectual disability, trauma and psychotherapy, London: Routledge 2009 (Taylor and Francis Group).

[40] Herman JL. Trauma and Recovery, Glenview, IL: Basic Books 1992; (Harper Collins).

[41] Bowlby J. Attachment and Loss: Vol 3. Loss: Sadness and Depression, Basic Books, New York 1980.

[42] Finkelhor D, Browne A. The Traumatic Impact of Child Sexual Abuse: A Conceptualization. American Journal of Orthopsychiatry 1985; 55(4): 530-541. http://dx.doi.org/10.1111/j.1939-0025.1985.tb02703.x
[43] Schalock RL, Verdugo MA. Quality of life for human service practitioners. Washington, DC: American Association on Mental Retardation 2002/2003.

[44] Schalock RL, Verdugo MA. El concepto de calidad de vida en los servicios y apoyos para personas con discapacidad intelectual. Siglo Cero 2007; 38(4): 21-36.

[45] Minuchin S, Fishman HC. Técnicas de terapia familiar Barcelona: Paidós 1984.

[46] Carter EA, McGoldrick M. Etapas de ruptura de la relación marital. En J. Navarro, Técnicas y programas en Terapia Familiar. Barcelona: Paidós 1992.

[47] Núñez B. El hijo adolescente con discapacidad en el seno de la familia. El Cisne, 2010.

[48] Bowlby J. Attachment and Loss: Vol. 1. Attachment, New York: Basic Books 1969/1982.

[49] Bowlby J. Attachment and Loss: Vol. 2. Separation: Anxiety and Anger, New York: Basic Books 1973.

[50] Ainsworth MDS, Blehar MC, Waters E, Wall S. Patterns of attachment: A psychological study of the strange situation. Hillsdale, NJ: Erlbaum 1978.

[51] Dio Bleichmar E. Manual de psicoterapia de la relación entre padres e hijos. Barcelona: Paidós 2005.

[52] Bowlby J. A secure base: Parent-child attachment and healthy human development. New York: Basic Books 1988

[53] Hughes J. Violence and health: The challenges of how we talk about, conceptualize, and address violence. The Canadian Journal of Nursing Research 2006; 38(4): 27-30.

[54] Marrone M. La teoría del apego: Un enfoque actual. Madrid: Psimática 2001.

[55] Steele K, Van der Hart O, Nijenhuis ERS. Tratamiento secuenciado en fases de la disociación estructural en la traumatización compleja: superar las fobias relacionadas con el trauma. Journal of Trauma \& Dissociation 2005; 6(3): 1153.

http://dx.doi.org/10.1300/J229v06n03 02

Received on 25-11-2015

DOI: http://dx.doi.org/10.6000/2292-2598.2016.04.01.4

(c) 2016 Núñez-Polo et al.; Licensee Lifescience Global.

This is an open access article licensed under the terms of the Creative Commons Attribution Non-Commercial License (http://creativecommons.org/licenses/by-nc/3.0/) which permits unrestricted, non-commercial use, distribution and reproduction in any medium, provided the work is properly cited. 